\title{
REVIEW
}

\section{Is increased antidepressant exposure a contributory factor to the obesity pandemic?}

\author{
SH Lee ${ }^{1}$, G Paz-Filho ${ }^{1}, C_{\text {Mastronardi }}{ }^{1}$, J Licinio $^{2}$ and M-L Wong ${ }^{2}$
}

\begin{abstract}
Major depressive disorder (MDD) and obesity are both common heterogeneous disorders with complex aetiology, with a major impact on public health. Antidepressant prescribing has risen nearly $400 \%$ since 1988 , according to data from the Centers for Disease Control and Prevention (CDC). In parallel, adult obesity rates have doubled since 1980, from 15 to 30 percent, while childhood obesity rates have more than tripled. Rising obesity rates have significant health consequences, contributing to increased rates of more than thirty serious diseases. Despite the concomitant rise of antidepressant use and of the obesity rates in Western societies, the association between the two, as well as the mechanisms underlying antidepressant-induced weight gain, remain under explored. In this review, we highlight the complex relationship between antidepressant use, MDD and weight gain. Clinical findings have suggested that obesity may increase the risk of developing MDD, and vice versa. Hypothalamic-pituitary-adrenal (HPA) axis activation occurs in the state of stress; concurrently, the HPA axis is also dysregulated in obesity and metabolic syndrome, making it the most well-understood shared common pathophysiological pathway with MDD. Numerous studies have investigated the effects of different classes of antidepressants on body weight. Previous clinical studies suggest that the tricyclics amitriptyline, nortriptyline and imipramine, and the serotonin norepinephrine reuptake inhibitor mirtazapine are associated with weight gain. Despite the fact that selective serotonin reuptake inhibitor (SSRI) use has been associated with weight loss during acute treatment, a number of studies have shown that SSRIs may be associated with long-term risk of weight gain; however, because of high variability and multiple confounds in clinical studies, the long-term effect of SSRI treatment and SSRI exposure on body weight remains unclear. A recently developed animal paradigm shows that the combination of stress and antidepressants followed by long-term high-fat diet results, long after discontinuation of antidepressant treatment, in markedly increased weight, in excess of what is caused by high-fat diet alone. On the basis of existing epidemiological, clinical and preclinical data, we have generated the testable hypothesis that escalating use of antidepressants, resulting in high rates of antidepressant exposure, might be a contributory factor to the obesity epidemic.
\end{abstract}

Translational Psychiatry (2016) 6, e759; doi:10.1038/tp.2016.25; published online 15 March 2016

\section{INTRODUCTION}

Major depressive disorder (MDD) and obesity are both common, heterogeneous disorders with complex aetiology, and pronounced public health impact. ${ }^{1,2}$ According to data from the World Health Organization (WHO), MDD has become the second most prevalent cause of illness-induced disability, affecting 350 million people worldwide. ${ }^{3}$ In the United States, costs related to MDD such as medical expenses are estimated to be $\$ 210.5$ billion a year. ${ }^{4,5}$ With a lifetime prevalence of $16.2 \%$, MDD is twice as common in women. Moreover, two-thirds of suicides are associated with MDD. ${ }^{1}$ In Australia, according to the 2011-2012 National Survey of Mental Health and Wellbeing, $9.7 \%$ of people aged $16-85$ years were affected by mood disorders. ${ }^{6}$ In Europe, 1 out of 15 people are known to suffer from MDD. ${ }^{7}$

Concomitantly, obesity is a debilitating epidemic affecting $34.9 \%$ of US adults (78.6 million individuals), resulting in estimated annual medical costs of $\$ 147$ billion in $2008 .^{8}$ Since 1962 , the prevalence of obesity among adults more than doubled, from 13.4 to $35.7 \%$ among American adults aged 20 and older, ${ }^{9}$ in a manner that parallels the increase in MDD treatment. Besides type 2 diabetes mellitus and cardiovascular diseases (CVDs), obesity has other disabling consequences, including cancer, $^{10}$ sleep disorders ${ }^{11}$ and psychological distress. ${ }^{12}$ In the past few decades, studies have addressed the relationship between obesity and MDD. ${ }^{13-18}$ Previous clinical findings have suggested that obesity could increase the risk of developing MDD, and vice versa. ${ }^{19-24}$ It has been suggested that obesity and MDD share common pathophysiology to a certain extent, yet the precise pathways and mechanisms for a causal association between MDD and obesity remain unknown.

In United States of America, over the past two decades, the rate of antidepressant use has increased nearly 400\%, where antidepressant drugs were the third most prescribed class of drugs for persons aged $18-44$ years in $2005-2008 .{ }^{25}$ In 2010, it was reported that 52.3 daily doses were prescribed for every 1000 inhabitants in European countries. ${ }^{26}$ In Australia, 34 million prescriptions were issued for mental health-related diseases in 2013-2014, and 67\% (23 million) of those were for

${ }^{1}$ Department of Genome Sciences, John Curtin School of Medical Research, Australian National University, Canberra, ACT, Australia and ${ }^{2}$ Pharmacogenomics Research Program, Mind and Brain Theme, South Australian Health and Medical Research Institute and Department of Psychiatry, School of Medicine, Flinders University, Adelaide, SA, Australia. Correspondence: Professor M-L Wong, Pharmacogenomics Research Program, Mind and Brain Theme, South Australian Health and Medical Research Institute and Department of Psychiatry, School of Medicine, Flinders University, PO Box 11060, Adelaide, SA 5001, Australia.

E-mail: mali.wong@sahmri.com

Received 25 September 2015; revised 25 January 2016; accepted 26 January 2016 
antidepressants. ${ }^{27}$ In 2012-2013, mental health-related prescriptions cost the Australian Government over $\$ 788$ million. ${ }^{27}$ With a rapid rise of individuals taking antidepressants, numerous studies have investigated the effects of different classes of antidepressants on body weight. Despite the concomitant occurrence of the frequent use of antidepressants and the high incidence of obesity in Western societies, the pathways and mechanisms by which antidepressants can induced weight gain remain unclear.

In this review, we examine the pathophysiology of MDD and obesity, and their complex interactions. More specifically, we discuss the role of antidepressant use in weight gain, and the role of interactions with environmental factors, such as stress.

\section{MDD}

The diagnosis of MDD is made in the presence of five or more of the following symptoms for a continuous 2-week period or longer, as described in the Diagnostic and Statistical Manual of Mental Disorders (DSM-5): (i) depressed mood most of the day, nearly every day; (ii) significant weight loss/gain or decrease/increase in appetite; (iii) markedly diminished interest or pleasure in almost all activities; (iv) insomnia or hypersomnia; (v) fatigue or loss of energy; (vi) psychomotor retardation or agitation; (vii) feelings of worthlessness; (viii) diminished ability to concentrate or make decisions; and (ix) recurrent thoughts of death. ${ }^{28}$ MDD is a complex disorder; its exact pathophysiology remains elusive, as does the mechanism of action of antidepressants. Over many decades, the pathophysiology of MDD was thought to be based on the hypothesis of monoamine depletion, supported by the fact that the monoamine oxidase inhibitors (MAOIs), a class of antidepressants, restored physiological levels of monoamine in the brain. ${ }^{29}$ Although monoamine levels can be restored acutely, within a few hours after treatment, full antidepressant action is achieved only after 3-4 weeks of treatment initiation. This gap between immediate biochemical effects and delayed clinical response fostered the development of new theories for the pathophysiological mechanism of MDD that go beyond the monoamine hypothesis.

Other theories for the underlying biology of MDD include the neuroendocrine, neuroimmune and neurotropic hypotheses. ${ }^{29,30}$ The neuroendocrine theory proposes that the pathophysiological mechanism of MDD involves abnormal homeostasis of the hypothalamus-pituitary-adrenal (HPA) axis, with overactivation of the stress response. ${ }^{30,31}$ Cortisol levels are often increased in the plasma of MDD patients, ${ }^{30,32}$ and antidepressant treatment downregulates the HPA axis response. ${ }^{30}$ Moreover, recent evidence points towards the importance of insulin-like growth factor 1 in MDD. ${ }^{33-36}$ It has been suggested that, in mice, insulinlike growth factor 1 deficiency is accompanied by impaired adult hippocampal neurogenesis and decreased total number of neurons in the hippocampus. ${ }^{33}$ In a mouse model, administration of insulin-like growth factor 1 via intracerebroventricular injection has an antidepressant-like action in rodents. ${ }^{33-36}$ Furthermore, it has been observed that the adipose tissue-derived hormone leptin has a potential role in MDD: circulating leptin levels are decreased in MDD patients and in individuals who attempt suicide, in comparison with healthy controls. ${ }^{37-40}$ In contrast, the relationship between antidepressant treatment and leptin levels remains less clear. Schilling et al. have shown that amitriptyline or mirtazapine antidepressant treatment increased plasma leptin concentrations, whereas the plasma leptin level remained unaltered with paroxetine and venlafaxine treatments. ${ }^{41}$ Furthermore, intrahippocampal, but not intrahypothalamic administration of leptin led to antidepressant-like action in rodents, suggesting that leptin-induced antidepressant actions were not secondary to leptin-induced metabolic effects. ${ }^{42}$

The neuroimmune theory proposes that immune mediators such as cytokines (e.g., interferons and interleukins) may have a role in $\mathrm{MDD}^{30}$ As those immune mediators modulate key functions such as sleep, appetite, cognition and temperature regulation, any alterations in those mediators can contribute indirectly to the pathogenesis of MDD, by disrupting vital functions. ${ }^{30}$ That theory is substantiated by the observation that the innate immune system is altered in MDD towards a proinflammatory state, and by the fact that some antidepressants act by reducing inflammation via cyclooxygenase inhibition.

In addition, cytokines can contribute to HPA axis hyperactivity, and affect the serotonergic, dopaminergic, glutamatergic and monoamonergic systems, contributing to MDD. ${ }^{43}$ Accordingly, pro-inflammatory cytokines stimulate glucocorticoid release by acting at all three levels of the HPA axis: at the paraventricular nucleus level, they stimulate the release of corticotropin-releasing hormone (CRH) level; at the pituitary level, they stimulate the release of adrenocorticotropin; and at the adrenal glands, they stimulate the release of glucocorticoids.

The neurotropic theory is a newer hypothesis for MDD, and it proposes that antidepressant treatment leads to acute restoration of monoamine levels in the brain, followed by changes in neuroplasticity via increased synaptic contacts and dendritic arborisation. ${ }^{44}$ The neurotropic hypothesis implies that neurotropic factors are the key factors in antidepressant action. ${ }^{29}$ These include the nerve growth factor (NGF) and the neurokine or neuropoetin superfamilies. The NGF superfamily includes NGF, brain-derived neurotropic factor (BDNF), neurotrophin-3 and neurotrophin-6. The antidepressant effect via BDNF has important roles in supporting neuronal survival and maintaining neuroplasticity. ${ }^{45}$ In rodent models of stress-induced depression, lower levels of BDNF in the hippocampus were restored by antidepressant treatment. ${ }^{44,46}$ Furthermore, antidepressant treatments have failed to elevate hippocampal neurogenesis at the subgranular zone in a mouse model of absence of BDNF-tyrosine receptor kinase $B$ (BDNF-TrkB) signalling. ${ }^{47}$ Consequently, neurotropic factors, such as BDNF, may have an important role in the mechanism of antidepressant action.

\section{OBESITY}

Obesity is primarily defined as the excess of fat mass of sufficient magnitude to produce adverse health consequences. It is diagnosed based on total body weight in relation to height (that is, body mass index (BMI) of $30 \mathrm{~kg} / \mathrm{m}^{2}$ and over), whereas overweight is diagnosed in the presence of BMI between 25 and $29.9 \mathrm{~kg} / \mathrm{m}^{2}$. ${ }^{48}$ As those diagnostic criteria do not take into account fat content, other measures of adiposity can also be used for the proper assessment of metabolic risk, such as waist circumference, waist-to-hip ratio, total body fat and body fat percentage. By employing those measures, one can identify individuals with normal body weight and excessive fat content ('metabolically obese, normal weight'), who are also at risk for metabolic diseases. The overly reductionistic explanation of the pathophysiology of obesity as solely due to energy imbalance resulting from excessive food intake and insufficient energy expenditure has evolved over time to become more nuanced. It is now known that the causes of obesity are complex, and many factors including environment, genetics, culture, food choices and hormonal factors contribute to obesity. ${ }^{49}$

Obesity is one component of a cluster of risk factors that increases the risk for the development of type 2 diabetes mellitus and CVD, known as metabolic syndrome (MetS). ${ }^{50}$ There is no consensus regarding the diagnosis of MetS; however, in 2009, a joint statement by various medical organisations was published, stating that obesity and insulin resistance are not prerequisites for MetS; three of the five following components would suffice for a diagnosis of MetS: elevated waist circumference (a measure of visceral obesity), high blood pressure (or antihypertensive drug treatment in a patient with a history of hypertension), high fasting 
hyperglycaemia (or drug treatment of elevated glucose), elevated triglycerides (or drug treatment for elevated triglycerides) and reduced high-density lipoprotein (HDL)-cholesterol (or drug treatment for reduced $\mathrm{HDL}$-cholesterol). ${ }^{51}$

\section{MDD AND OBESITY}

Obesity and MDD have in common several biological aspects, as described by Bornstein et al. ${ }^{52}$ Both disorders frequently co-exist, causing substantial health problems. However, those disorders sometimes do not occur concurrently; obesity can follow depression that occurred earlier in life. On the one hand, depressed mood can be a side effect of obesity treatments, which is further confounded by changes in lifestyle. On the other hand, weight gain can be a side effect of antidepressant treatments. From the pathophysiological point of view, the regulation of mood and body weight is characterised by shared neuropeptidergic and neurotransmitter systems, such as $\mathrm{CRH}$, neuropeptide $Y$ (NPY), serotonin and norepinephrine. Both disorders can lead to CVD, and genetic polymorphisms may underlie the predisposition both to CVD and to depression. Finally, most drugs used in depression and in obesity predominantly affect either serotonin or norepinephrine.

In the past few decades, studies have addressed the relationship between obesity and MDD, and they have suggested that both disorders share a common pathophysiology to a certain extent. However, because of the heterogeneity of clinical data and the methodology used in different studies, variations do exist across studies. Cross-sectional and longitudinal studies have been conducted in order to understand the casual relationship between MDD and obesity, and vice versa. ${ }^{13-18}$ Several studies have pinpointed that obesity is positively associated with MDD. In the cross-sectional study conducted by Rosmond et al., waist circumference (a measure of visceral adiposity) was associated with symptoms of MDD among Swedish men. ${ }^{13}$ In another study, obesity was associated with increased risk for affective disorders in a cluster sample of young German women. ${ }^{15}$ In the third National Health and Nutrition Examination Survey (NHANES-III), obese individuals with $\mathrm{BMI}>40$ were more likely to suffer from MDD than individuals with BMI of $30-34.9 \mathrm{~kg} / \mathrm{m}^{2} .{ }^{16}$ In longitudinal studies with a 5-year follow-up, obese individuals had an increased odds ratio of 2.13 for $M D D$, indicating that obese individuals are twice as likely to suffer from MDD in comparison with non-obese individuals. ${ }^{17}$ Another study suggested that obesity is associated with an $\sim 25 \%$ increase in odds of mood and anxiety disorders. ${ }^{53}$ In a meta-analysis of cross-sectional studies in the general population, a significant positive association between depression and obesity in the general population was observed, which was stronger among women. ${ }^{54}$ Another meta-analysis evaluating the longitudinal, bidirectional evidence of the association between depression and obesity showed that obesity increased the risk of onset of depression (unadjusted odds ratio (OR), 1.55), and that depression also increased the odds for developing obesity $(\mathrm{OR}, 1.58) .^{55}$

MDD may in some cases be the causal trigger leading to obesity. This hypothesis is supported by the meta-analysis by Luppino et al., where obesity at baseline increased the risk of onset of depression at follow-up (unadjusted OR of 1.55 ).$^{56}$ In a New Zealand-based longitudinal study, adolescent girls suffering from MDD had a twofold increase in the risk for developing obesity in adulthood than non-depressed ones. ${ }^{18}$ Other studies have also demonstrated that depressive symptoms during childhood are associated with weight gain and obesity during young adulthood, ${ }^{57}$ and that baseline depression is associated with a 5year increase in visceral obesity. ${ }^{58}$

In addition to these clinical findings, obesity and MDD are influenced by gene-environment interactions. ${ }^{59}$ In fact, there have been association studies of obesity that identified genes that are hypothetically involved in depression. Two of them, the glucocorticoid receptor $N R 3 C 1$ (ref. 60) and the $C R H$ genes ${ }^{61}$ are related to the dysregulation of the HPA. Similarly, the BDNF Val66Met polymorphism is also associated with obesity and depression. $^{62}$

\section{MDD AND METS}

Studies have shown that the prevalence of MetS is greater in individuals with MDD symptoms. ${ }^{19-22}$ Women with a history of MDD have twice the chance of developing MetS than women without such history. ${ }^{20}$ In longitudinal studies of 7-15 years of follow-up, women with symptoms of MDD and increased tension and anger at baseline had a higher risk of developing MetS. ${ }^{24}$ Furthermore, the risk for MetS was elevated from 1.21- to 2.12-fold (95\% confidence interval $(\mathrm{Cl}) 1.00-4.25)$ in individuals with more severe MDD symptoms or very stressful life events. ${ }^{23}$ These crosssectional and longitudinal studies have shown that MDD symptoms and stressful life events increase the risk of developing MetS. Thus, current studies clearly support that there is a relationship between MDD and MetS, which also appears to be bidirectional: according to a recent meta-analysis of crosssectional and cohort studies, the pooled crude OR between depression and MetS was $1.42(95 \% \mathrm{Cl} 1.28-1.57)$. In the same meta-analysis, the pooled adjusted OR was 1.49 (95\% Cl 1.19-1.89) for MetS predicting depression risk, and 1.52 (95\% Cl 1.20-1.91) for depression predicting MetS risk. $^{63}$ Other meta-analyses showed that patients with MDD had a higher MetS prevalence (OR 1.54 (95\% Cl 1.21-1.97)), with higher risk for hyperglycaemia (OR $1.33(95 \% \mathrm{Cl} 1.03-1.73)$ ) and hypertriglyceridaemia (OR 1.17 $(95 \% \mathrm{Cl} 1.04-1.30)) .64$ A common pathophysiological pathway between MDD and metabolic dysregulation involves the HPA axis, as described below.

\section{THE INTERPLAY BETWEEN STRESS, MDD AND OBESITY}

Chronic stress is a state where there is persistent activation of the HPA axis. ${ }^{65}$ Moreover, the HPA axis is also dysregulated in obesity, making this axis a shared pathophysiological pathway with MDD. ${ }^{65}$ During stress, $\mathrm{CRH}$ is released from the paraventricular nucleus of the hypothalamus, stimulating the secretion of adrenocorticotropin, which in turn stimulates cortisol secretion from the adrenal glands. ${ }^{65}$ In order to compensate for the resulting hypercortisolism, the negative feedback mechanism of glucocorticoid receptors is activated and downregulates the cortisol stress response. ${ }^{65}$ However, in MDD, an excess amount of cortisol in circulation and the over-expression of mineralocorticoid and glucocorticoid receptor results in decreased negative feedback, leading to enduring hypercortisolism. ${ }^{66}$ Cortisol facilitates lipid accumulation by activation of glucocorticoid receptor; as these receptors are highly expressed in the intra-abdominal and visceral areas, this is one of the major pathways leading to visceral and central obesity, and consequently, metabolic complications. ${ }^{65}$ Inflammation is another pathway that links obesity to $\mathrm{MDD}^{56}$ as both disorders are associated with the activation of inflammatory pathways. ${ }^{56}$ However, studies have also demonstrated a pro-inflammatory state in lean depressed individuals, suggesting that the pro-inflammatory state in MDD may not be primarily related to obesity. ${ }^{67}$ The simultaneous activation of inflammatory pathways by depression and by obesity can only be detrimental. Furthermore, increased insulin resistance, frequently observed in obesity and in pro-inflammatory states, may induce alterations in the brain and increase the risk of MDD. ${ }^{56}$

\section{ANTIDEPRESSANTS}

In 1950s, the antidepressant effects of MAOls were first discovered when tuberculosis patients were treated with iproniazid. ${ }^{68-70}$ Shortly after iproniazid treatment initiation, patients experienced 
an antidepressant-like effect with elevated mood. Subsequently, it was shown that iproniazid is a MAOI, with the ability to inhibit the enzyme monoamine oxidase to catabolise monoamines, preventing monoamine depletion in the brain. ${ }^{69}$ Since then, it has been hypothesised that a depletion in other neurotransmitters such as norepinephrine, dopamine and serotonin contributes to cause MDD. ${ }^{69}$ There are different classes of antidepressant drugs, and, primarily, they have been known to work by modulating neurotransmitter levels in the brain. ${ }^{4}$ Older generation antidepressants include MAOls and tricyclics (TCAs), ${ }^{4}$ whereas newer types of antidepressants have greater specificity and include selective reuptake inhibitors (selective serotonin reuptake inhibitor, SSRI), serotonin and norepinephrine reuptake inhibitors (SNRIs), and norepinephrine and dopamine reuptake inhibitors. ${ }^{4}$ Other antidepressants include tetracyclics and serotonin antagonist and reuptake inhibitors.

Currently, non-selective MAOls on the market include phenelzine (Nardil), isocarboxazid (Marplan) and tranylcypromine (Parnate) ${ }^{68}$ Selective MAOls include selegiline (Emsam) and clorgyline. ${ }^{68}$ However, the use of such drugs declined because of their serious side effects, such as those related to food and drug interactions. MAOls are used as a third or fourth line of the therapy when other types of therapy have failed. ${ }^{68}$

The therapeutic action of TCAs is known to occur via inhibition of serotonin and norepinephrine reuptake. ${ }^{71}$ These include imipramine (Tofranil), amitriptyline (Elavil), nortiptyline (Allegron), trimipramine (Surmontil), protriptyline (Concordin) and iprindole (Prondol). ${ }^{72}$ However, TCAs have multiple nonspecific actions that are associated with side effects. ${ }^{71}$ These nonspecific actions include anticholinergic-antimuscarinic (M1), a-1 adrenergic antagonistic and antihistaminergic activities $(\mathrm{H} 1) .{ }^{71}$ Furthermore, large doses of TCAs inhibit sodium channels, leading to lethal cardiac arrhythmias and seizures. ${ }^{71}$ For this reason, TCA antidepressants are used with caution in patients with high risk of CVD. ${ }^{73-75}$ Moreover, TCA-induced weight gain is one of the main reasons for the discontinuation of treatment within 1 month. ${ }^{76}$

Since the US Food and Drug Administration's approval of fluoxetine (Prozac) in 1988, SSRIs have been the most prescribed antidepressants on the market. ${ }^{77}$ They act by inhibiting serotonin (5-hydroxytryptamine, 5HT) uptake. Since then, other SSRIs have emerged in the market, and these include citalopram (Celexa), fluvoxamine (Floxyfral), paroxetine (Aropax) and sertraline (Zoloft). ${ }^{78}$ Although SSRls have been well tolerated by patients because of fewer side effects than previous drug, there is still a substantial profile of adverse drug reactions, such as sexual dysfunction, drowsiness, weight gain, dry mouth, insomnia, fatigue, nausea, dizziness and tremors. ${ }^{79,80}$ The tolerability of a drug can be assessed by discontinuation rates in clinical trials. The discontinuation rate within 2 months for fluvoxamine was $\sim 70 \%$, followed by fluoxetine (45\%) and sertraline (40\%). ${ }^{81-83}$

After the successful development of SSRIs, it was proposed that the simultaneous action of selective noradrenaline and serotonin reuptake could provide better efficacy. ${ }^{84-86}$ Thus, antidepressant SNRIs are as effective as TCAs, but side effects such as cardiac arrhythmias and seizures are significantly reduced. ${ }^{84-86}$ SNRIs available on the market include duloxetine (Cymbalta), venlafaxine (Effexor), desvenlafaxine (Pristiq) and milnacipran (Savella).

\section{CLINICAL FINDINGS ON THE EFFECTS OF ANTIDEPRESSANT USE ON BODY WEIGHT}

TCA

In the study conducted by Berken et al., low to moderate doses of the TCAs amitriptyline (150 mg per day), nortriptyline $(50 \mathrm{mg}$ per day) and imipramine ( $80 \mathrm{mg}$ per day) were associated with a mean weight gain of 1.3-2.9 lbs per month, and the trend of weight gain remained linear overtime. ${ }^{76}$ Furthermore, it was suggested that the main reason for patients discontinuing treatment was excessive weight gain. ${ }^{76}$ In more recent studies, TCA antidepressants have been shown to increase the OR for MetS to 2.30 (95\% Cl 1.21-4.36), and this was independent of depression severity. ${ }^{87}$ In a 4 -year follow-up study, the mean weight gain in patients treated with unspecific antidepressants was $4.3 \%$, whereas in control subjects it was $2.5 \%$. Moreover, weight gain for the TCA antidepressant users was $4.7 \%$ (Table 1). ${ }^{88}$

Sussman et al. observed that during acute treatment with imipramine, $4.9 \%$ patients significantly gained weight; this rate increased to $24.5 \%$ in long-term treatment. ${ }^{93}$ Nortriptyline (TCA) was associated with an increase in BMI of $0.44 \mathrm{~kg} / \mathrm{m}^{2}$ over a 12week period. ${ }^{94}$ Furthermore, 6 months of nortriptyline treatment was associated with an increase of $0.64 \mathrm{~kg} / \mathrm{m}^{2}$ in BMI. ${ }^{94}$

\section{SSRIS AND SNRIS}

Initially, when patients were treated acutely with SSRIs weight loss was observed. ${ }^{95}$ Currently, SSRIs are useful for the treatment of obese patients with binge eating disorder, given their antiimpulsive action. However, their clinical relevance for weight loss in these patients remains unclear. In the recently published Endocrine Society Clinical Practice Guideline on the Pharmacological Management of Obesity, the use of SSRIs is not listed as a therapeutic tool. ${ }^{96}$ Despite the fact that SSRI use has been associated with weight loss when acutely treated, a number of studies have shown SSRIs to be associated with long-term risk of weight gain. ${ }^{79,89,91,92}$ However, the number of long-term studies over the period of 1 year is limited, and there is a need for studies specifically investigating the long-term effects of SSRIs on body weight.

Cascade et al. reported that $6 \%$ of patients using SSRIs gained weight. ${ }^{79}$ The Canadian National Population Health Survey (NPHS) is a longitudinal study that has found that SSRIs and the SNRI venlafaxine use are associated with significant weight gain. ${ }^{89} \mathrm{~A}$ long-term comparison study investigated the effects of different types of SSRI on weight gain in patients with panic disorder. It showed that paroxetine, fluoxetine, citalopram and fluvoxamine induced weight gain of, respectively, $8.2 \pm 5.4,5.2 \pm 4.4,6.9 \pm 5.7$ and $6.3 \pm 4.2 \mathrm{~kg}$ in a 1-year period. ${ }^{91}$ Michelson et al. observed changes in body weight during a 1-year trial period of fluoxetine treatment. The initial 12-week period was associated with weight loss of $0.35 \mathrm{~kg}$, and 50 weeks of treatment resulted in weight gain of $3 \mathrm{~kg} .^{92}$

In a prospective 4-year follow-up study, SSRI-treated patients had weight gain of $4.6 \%{ }^{88}$ In the study conducted by Sussman et al., $17.9 \%$ of SSRI users experienced significant weight gain $\geqslant 7 \% .{ }^{93}$ Escitalopram (SSRI) treatment resulted in an increase of 0.05 in BMl scores during the first 12 weeks, and there was an increase of 0.12 in BMI scores after 6 months of treatment initiation. $^{94}$

In addition to the clinical studies described above, case studies have reported extreme weight gain in patients with SSRI treatment. ${ }^{97,98}$ In the study conducted by Bouwer et al., treatment with citalopram led to weight gain and carbohydrate craving in eight out of eighteen patients. In a 4-week period, one female patient gained $8 \mathrm{~kg}$, whereas in a 5 -week period one male patient gained $9 \mathrm{~kg} .{ }^{98}$ In another case study, a 33-year-old schizophrenic female patient was treated with fluoxetine ( $40 \mathrm{mg}$ per day) for a 9month period following antipsychotic treatment with risperidone (6 mg per day) and clorazepate (15 mg per day).$^{97}$ The patient was discontinued from fluoxetine because she underwent excessive weight gain $(52 \mathrm{~kg})$ accompanied with carbohydrate craving. ${ }^{97}$ Therefore, some individuals may be more sensitive to weight gain induced by SSRIs than others. ${ }^{97,98}$ 
Table 1. Clinical studies on the effects of antidepressants on body weight

\begin{tabular}{|c|c|c|c|}
\hline Study & Significance & Sample size/duration & Limitation \\
\hline $\begin{array}{l}\text { Major depression, } \\
\text { antidepressant medication } \\
\text { and the risk of obesity }\end{array}$ & $\begin{array}{l}\text { SSRI and venlafaxine were significantly } \\
\text { associated with obesity. } \\
\text { There was no significant association } \\
\text { between TCA or antipsychotic } \\
\text { medications with obesity }\end{array}$ & $\begin{array}{l}\text { NHPS sample (1994-2004) } \\
\qquad n=17276\end{array}$ & $\begin{array}{l}\text { Confounded by prescription. } \\
\text { Physicians may have specifically } \\
\text { selected these medications for } \\
\text { use in patients who they } \\
\text { believe to be most at risk of } \\
\text { weight gain }\end{array}$ \\
\hline $\begin{array}{l}\text { MetS abnormalities are } \\
\text { associated with severity of } \\
\text { anxiety and depression and } \\
\text { with tricyclic antidepressant } \\
\text { use }\end{array}$ & $\begin{array}{l}\text { Tricyclic antidepressants increased } \\
\text { the odds for MetS }\end{array}$ & $n=2981$ & $\begin{array}{l}\text { The main focus of this study is } \\
\text { on MetS and different levels of } \\
\text { depression }\end{array}$ \\
\hline $\begin{array}{l}\text { Long-term weight gain in } \\
\text { patients treated with open-label } \\
\text { olanzapine in combination with } \\
\text { fluoxetine for major depressive } \\
\text { disorder }^{90}\end{array}$ & $\begin{array}{l}\text { Patients were treated with a combination } \\
\text { of olanzapine and fluoxetine (OFC). } \\
\text { Increases in fluoxetine dose were predictors } \\
\text { of weight gain. Long-term ( } 76 \text { weeks) OFC } \\
\text { treatment may lead to a large percentage } \\
\text { ( } 56 \% \text { ) of patient meeting the criteria for } \\
\text { significant weight gain }(>7 \%)\end{array}$ & $n=549$ & \\
\hline $\begin{array}{l}\text { Real-world data on SSRI } \\
\text { antidepressant side effects }\end{array}$ & $\begin{array}{l}36 \% \text { of patients experienced side } \\
\text { effects associated with SSRI. } \\
\text { Forty-nine patients had weight gain }\end{array}$ & $n=700$ Patients & \\
\hline $\begin{array}{l}\text { A naturalistic long-term } \\
\text { comparison study of selective } \\
\text { serotonin reuptake inhibitors } \\
\text { in the treatment of panic } \\
\text { disorder }\end{array}$ & $\begin{array}{l}\text { Weight gain } \\
\text { Paroxetine: } 8.2 \pm 5.4 \mathrm{~kg} \\
\text { Fluoxetine: } \\
5.2 \pm 4.4 \mathrm{~kg} \\
\text { Citalopram: } 6.9 \pm 5.7 \mathrm{~kg} \\
\text { Fluvoxamine: } 6.3 \pm 4.2 \mathrm{~kg}\end{array}$ & $\begin{array}{l}\text { Duration: } 1 \text { year } \\
\quad n=200\end{array}$ & \\
\hline $\begin{array}{l}\text { Changes in weight during } \\
\text { a 1-year trial of fluoxetine }\end{array}$ & $\begin{array}{l}\text { 12-Week treatment: }-0.35 \mathrm{~kg} \\
50 \text {-Week treatment: }+3 \mathrm{~kg}\end{array}$ & $\begin{array}{l}\text { Duration: } 50 \text { weeks } \\
\qquad n=395\end{array}$ & \\
\hline $\begin{array}{l}\text { Changes in body weight } \\
\text { during treatment with the } \\
\text { new antidepressant Nefazodone, } \\
\text { three SSRIs Fluoxetine, Setraline, } \\
\text { Paroxetine, and the tricyclic } \\
\text { Imipramine }\end{array}$ & $\begin{array}{l}\text { Significant weight loss or gain was, } \\
\text { respectively, defined as } \leqslant 7 \text { and } \geqslant 7 \% \\
\text { change in body weight from baseline. } \\
\text { Study } 1 \\
\text { Acute phase trial } \\
\text { SSRI: } 4.3 \% \text { of treated patients lost weight } \\
\text { at any point } \\
\text { Nefazodone: } 1.7 \% \text { of treated patients lost } \\
\text { weight at any point } \\
\text { Long-term phase trial } \\
\text { SSRl: } 17.9 \% \text { of treated patients had } \\
\text { weight gain } \\
\text { Nefazodone: } 8.3 \% \text { of treated patients } \\
\text { had weight gain } \\
\text { Study } 2 \\
\text { Acute phase trial } \\
\text { Imipramine: } 4.9 \% \text { of treated patients } \\
\text { had weight gain } \\
\text { Nefazodone: } 0.9 \% \text { of } \\
\text { treated had weight gain } \\
\text { Long-term phase trial } \\
\text { Imipramine: } 24.5 \% \text { of treated patients } \\
\text { had weight gain } \\
\text { Nefazodone: } 9.5 \% \text { of } \\
\text { treated patients had weight gain }\end{array}$ & 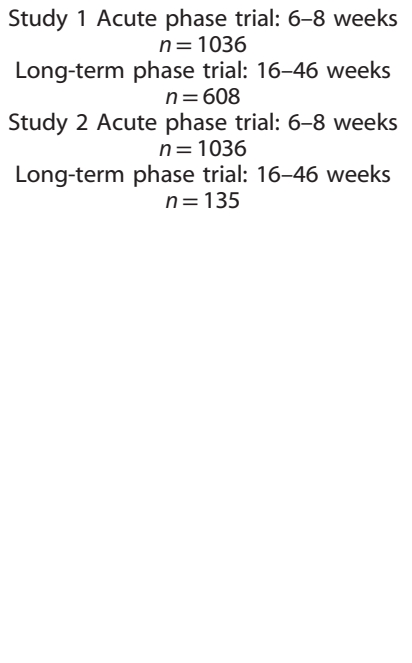 & \\
\hline TCA-induced weight gain ${ }^{76}$ & $\begin{array}{l}\text { TCA antidepressants } \\
\text { Amitriptyline, nortriptyline and imipramine } \\
\text { induced weight gain of } 1.3-2.9 \mathrm{lbs} \text { per month, } \\
\text { and weight increased linearly overtime }\end{array}$ & $\begin{array}{c}\quad n=40 \\
\text { Average of } 6 \text {-months treatment }\end{array}$ & \\
\hline $\begin{array}{l}\text { Body weight gain during } \\
\text { nortriptyline (TCA) or } \\
\text { escitalopram (SSRI) treatment }{ }^{94}\end{array}$ & $\begin{array}{l}\text { Nortriptyline } \\
\text { First } 12 \text { weeks: }+1.22 \mathrm{~kg}, \mathrm{BMI} \text { score increase of } 0.44 \\
\text { After } 6 \text { months: }+1.82 \mathrm{~kg}, \mathrm{BMI} \text { score increase of } \\
0.64 \\
\text { Escitalopram } \\
\text { First } 12 \text { weeks: }+0.14 \mathrm{~kg}, \mathrm{BMl} \text { score increase of } 0.05 \\
6 \text { Months: }+0.34 \mathrm{~kg}, \mathrm{BMl} \text { score increase of } 0.12\end{array}$ & $\begin{array}{l}n=630 \\
12 \text { weeks and } 6 \text { months of treatment }\end{array}$ & \\
\hline $\begin{array}{l}\text { Weight gain associated with } \\
\text { tricyclic or SSRI treatment }\end{array}$ & $\begin{array}{l}\text { Average weight gain of } 1.4 \mathrm{~kg}(2.5 \%) \text { in the control } \\
\text { group and } 2.5 \mathrm{~kg}(4.3 \%) \text { among users of } 200 \\
\text { defined daily doses of antidepressant }\end{array}$ & $\begin{array}{c}n=5537 \\
4 \text { years }\end{array}$ & \\
\hline
\end{tabular}




\section{META-ANALYSIS STUDY}

Recently, Serretti et al. performed a meta-analysis on the effects of antidepressants on body weight. ${ }^{95}$ The study showed that acute treatment with fluoxetine and bupropion was associated with significant weight loss of 0.94 and $1.13 \mathrm{~kg}$, respectively. ${ }^{95}$ Imipramine was associated with non-significant weight loss of $0.2 \mathrm{~kg}$, and mirtazapine was associated with significant weight gain of $1.74 \mathrm{~kg} .{ }^{95}$ When considering treatment periods longer than 4 months, imipramine was associated with non-significant weight loss of $0.04 \mathrm{~kg}$, bupropion with significant weight loss of $1.87 \mathrm{~kg}$ and fluoxetine with non-significant weight loss of $0.31 \mathrm{~kg}^{95}$ In contrast, mirtazapine was associated with non-significant weight gain of $2.59 \mathrm{~kg}(P<0.07)$ with upper limit of $5.41 \mathrm{~kg}$. ${ }^{95}$

\section{LIMITATIONS OF CURRENT FINDINGS}

Although these previous studies described the effects of antidepressants on body weight, there are multiple problems in clinical observations because of the methods used. Most previous data on antidepressant-induced weight gain were extracted from drug trials of antidepressant medications or larger cross-sectional observational studies investigating the broad spectrum of MDD research. Confounding effects such as physicians specifically selecting antidepressant medication taking into consideration the risk of weight gain could not be eliminated. ${ }^{89}$ Moreover, as described previously, weight gain is one of the most undesired effects of treatment, and one of the major reasons for discontinuing treatment within the first 2 months of treatment initiation. ${ }^{94}$ In most cases there was no long-term follow-up reported that would allow us to ascertain the impact of antidepressant treatment or exposure over the lifetime.

\section{MECHANISM PROPOSED OF ANTIDEPRESSANT-INDUCED WEIGHT GAIN}

Central and peripheral mechanisms of appetite and feeding behaviour regulation are complex; regulatory factors such as neurotransmitters, neuropeptides and hormone-like peptides have a role in orchestrating appetite, feeding behaviours and metabolic pathways. ${ }^{99}$ In previous studies, it has been suggested that weight gain associated with antidepressants reflects the action of monoamine pathways, which include serotonergic, adrenergic, histaminergic, cholinergic and dopaminergic receptors. The specific mechanisms of action of different antidepressants on weight are described below (Figure 1).

\section{MIRTAZAPINE}

Mirtazapine (SNRI) has been associated with weight gain. The mechanism of mirtazapine involves the blockade of a2-adrenergic receptors, together with affinity for histamine $\mathrm{H} 1$ receptors and low affinity for dopaminergic D1 and D2 receptors. ${ }^{95}$ It has been suggested that the histaminergic system is involved in appetite and feeding control. ${ }^{100}$ These histaminergic cell bodies are situated in a specific region called the tuberomammilary nucleus of the posterior hypothalamus. ${ }^{100}$ Histaminergic receptors have been shown to interact with orexigenic neuropeptides such as orexin A, NPY and ghrelin. ${ }^{101}$ Anti-histaminergic effects of mirtazapine were associated with enhanced appetite by activation of ghrelin and NPY. ${ }^{95,101}$ Furthermore, clinical doses of mirtazapine blocked both $5 \mathrm{HT} 2$ and $5 \mathrm{HT} 3$ receptors. ${ }^{99} 5 \mathrm{HT} 2$ receptors have an essential role in appetite, and antagonising $5 \mathrm{HT} 2$ results in weight gain. $^{99}$

\section{BUPROPION}

In contrast to mirtazapine, bupropion has been known to induce significant weight loss. ${ }^{95}$ The mechanism of action of bupropion is determined by its effect increasing dopamine and norepinephrine neurotransmission. ${ }^{95}$ Bupropion and its metabolites selectively inhibit dopamine and norepinephrine reuptake pumps, and may also alter the release of dopamine and norepinephrine; yet, it does not induce effects on postsynaptic receptors including histamine, $a$ - or $\beta$-adrenergic, serotonin, dopamine receptors; it is also a weak nicotinic acetylcholine receptor antagonist. Moreover, reduced dopaminergic tone in the hypothalamus of obese individuals may be reversed by bupropion by increasing the activity of the hypothalamic melanocortin system, which is an important component in the regulation of homeostatic energy balance. ${ }^{102}$

\section{TCA (AMITRIPTYLINE)}

The pharmacological actions of TCAs are known to be nonselective and these results in side effects associated with significant weight gain. Amitriptyline has high affinity for aadrenergic, histaminergic and cholinergic receptors. ${ }^{95}$

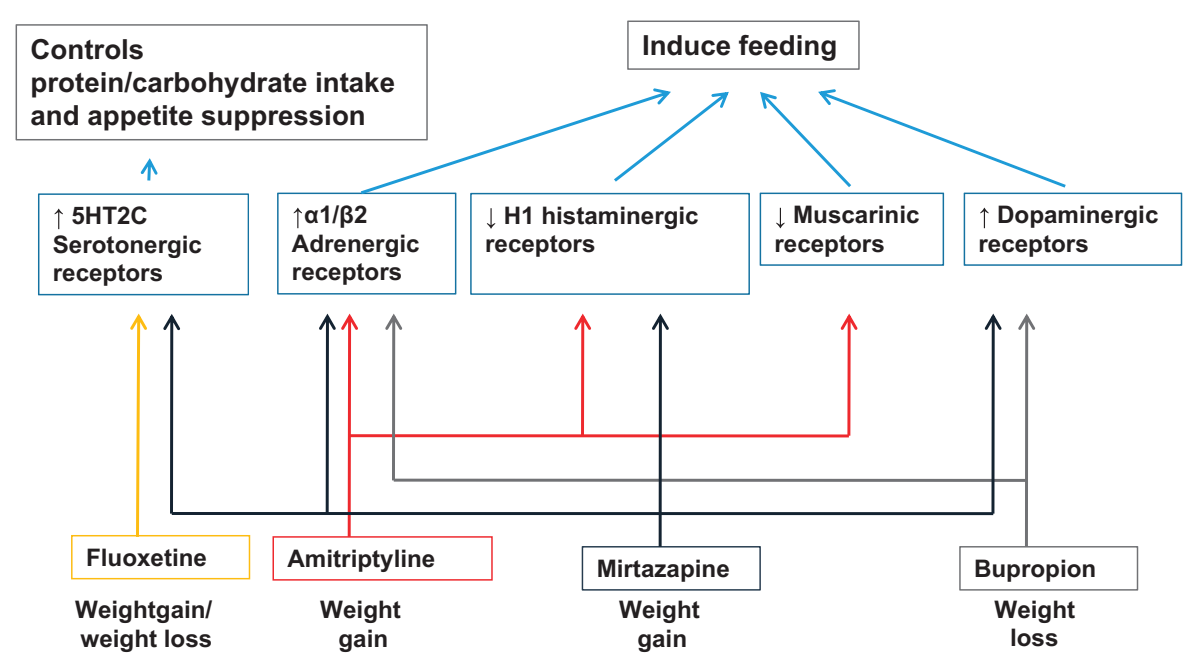

Figure 1. Mechanism of monoamine neurotransmission in antidepressant-induced weight gain. Note: $\uparrow$ denotes increased activation; $\downarrow$ denotes decreased activation. 
Table 2. Animal models of diet-induced obesity

\begin{tabular}{|c|c|c|c|}
\hline Study & High-fat diet & Metabolic factors & Study duration \\
\hline Dourmashikin et al. ${ }^{124}$ & $50 \%$ fat content & $\begin{array}{l}\text { Increased levels of leptin, insulin and lipoprotein lipase in adipose tissue. } \\
\text { Hyperphagia, enhanced circulating triglycerides, nonesterified fatty acids } \\
\text { and enhanced glucose, galanin. Increased } \beta \text {-hyroxyacyl-coaldehydrogenase } \\
\text { level in muscle }\end{array}$ & 3 Weeks \\
\hline Dourmashikin et al. ${ }^{125}$ & $45-60 \%$ fat content & $\begin{array}{l}\text { Elevated leptin, insulin, triglyceride, glucose, lipoprotein lipase activity in } \\
\text { adipose tissue }\end{array}$ & 4-6 Weeks \\
\hline Madsen et al. ${ }^{121}$ & $31.8 \%$ fat content & $\begin{array}{l}\text { Development of visceral obesity, hyperleptinaemia, hyperinsulinemia and } \\
\text { dyslipidaemia, and decrease in glucose tolerance }\end{array}$ & 9 Months \\
\hline
\end{tabular}

\section{SSRI (FLUOXETINE)}

Fluoxetine, a SSRI, has weight-reducing effects acutely. Fluoxetine has significant affinity for $5 \mathrm{HT} 2 \mathrm{C}$ receptors, which have a role in appetite suppression. In addition, fasting plasma leptin levels (an anorexigenic adipokine) were increased in patients treated with either imipramine or fluoxetine. ${ }^{99,103}$ In an acute experiment, fluoxetine injections in obese and lean rats resulted in reduced food intake. ${ }^{104}$ In these rats, fluoxetine significantly reduced NPY levels in the paraventricular nucleus of the hypothalamus. ${ }^{104}$ Acute weight loss is due to regulation of the carbohydrate/protein ingestion ratio, which is known to occur through $5 \mathrm{HT} .{ }^{99}$ Nevertheless, it would be essential to elucidate the mechanism of longterm effect of fluoxetine on body weight, which remains unclear. ${ }^{99}$

\section{ANIMAL MODELS OF DEPRESSION AND OBESITY}

Animal models of stress and depression

In the past, different attempts have been made to develop an animal model that mimics the clinical manifestations of MDD. ${ }^{105}$ MDD is a complex disorder, and it remains controversial whether animal models of depression mimic the depressive state of humans. Therefore, Willner et al. proposed that animal models of depression should fulfil a set of validity criteria, which included predictive, face and construct validities. ${ }^{106}$ Predictive validity is based on whether the animal model shows reliable pharmacological effects of antidepressants. ${ }^{107}$ Face validity assesses both treatment features of chronic antidepressant therapy and symptomatic features. ${ }^{107}$ The meaning of construct validity is rather complex, and is defined as having both behaviour and features of depression such as 'helplessness or anhedonia'. ${ }^{107}$ Furthermore, arising evidence suggests that pathophysiological changes in the neuroendocrine system, such as in the HPA axis and hippocampal structural changes in the process of neurogenesis, may be important biomarkers to validate an animal model of depression. ${ }^{105,107}$ According to the study conducted by Willner et al., only a few models passed all three criteria, and these models include chronic unpredictable stress, learned helplessness and intracranial self-stimulation. ${ }^{106}$ For these reasons, most of these animal models are referred as 'animal models of stress' instead of 'animal models of depression'. ${ }^{106}$

In animal models, behavioural testing has been used to screen the antidepressant effects of drugs. The most classic tests are known as the forced swimming test and the tail suspension test. Both forced swimming test and the tail suspension test are based on the despair behaviour, identified with immobility and lack of motivation to escape, and antidepressants have been demonstrated to reverse these behaviours. ${ }^{108,109}$ Behavioural tests that include novelty suppressed feeding, open field and elevated plus maze have been used to screen anxiety-related behaviours in animal models of depression, ${ }^{110,111}$ whereas cognitive tests, such as the Morris water maze, have been used to assess spatial memories and cognitive deficits associated with hippocampal atrophy. ${ }^{112}$ Furthermore, anhedonic behaviour has been tested by the sucrose preference test. ${ }^{113}$

\section{ANIMAL MODELS OF OBESITY}

At present, there are various types of animal models of obesity. These include spontaneous mutants such as the ob/ob and the $\mathrm{db} / \mathrm{db}$ mouse models, genetically engineered models of the $\mathrm{Mc} 4 \mathrm{r}$ gene and those based on environmental factors such as dietinduced obesity (DIO). ${ }^{114-117}$

\section{ANIMAL MODELS OF GENETIC OBESITY}

Leptin is an adipocyte-derived hormone encoded by the $o b$ gene. ${ }^{115,116}$ About two decades ago, the discovery that a genetic mutation in the $o b$ gene caused leptin deficiency and severe obesity showed that leptin is a critical molecule in the regulation of energy expenditure, food intake and attenuation of adipose mass. ${ }^{115,116}$ It was demonstrated that leptin has a high binding affinity in the hypothalamus, and it inhibited the orexigenic hormone NPY gene expression and synthesis. ${ }^{118}$

Further along, other obesity animal models have included the $\mathrm{db} / \mathrm{db}$ model and melanocortin- 4 receptor null mouse, which are characterised by elevated leptin levels and failure to attenuate obesity after leptin treatment, have provided the foundation for the concept of leptin resistance and hyperleptinaemia. ${ }^{115,117}$

\section{ANIMAL MODELS OF DIO}

In 1949, animal models of DIO were initially achieved by ad libitum feeding of a semi-liquid palatable diet. ${ }^{119}$ Since then, there has been an extensive number of studies seeking to achieve an optimal method for DIO using various methods. These methods included determining the optimal composition and duration of a diet, age and the genetic background of an animal model to induce DIO (Table 2). ${ }^{119}$ Recently, a study conducted by Buettner et al. concluded that the optimal condition for DIO in an animal model involved a semi-purified high animal fat diet of $40 \%$ of energy, with a limited amount of 3-polyunsaturated fatty acids 
Table 3. Effects of antidepress ants on the body weight of animal models

\begin{tabular}{|c|c|c|c|c|c|}
\hline Species & Treatment/duration & Proposed mechanism/pathway & Effect on body weight & Diet & Reference \\
\hline $\begin{array}{l}\mathrm{Fa} / \mathrm{Fa} \\
\text { Zuker rats }\end{array}$ & $\begin{array}{l}\text { Fluvoxamine }\left(25 \mathrm{mg} \mathrm{kg}^{-1}\right) \\
\text { treatment for } 7 \text { days }\end{array}$ & $\begin{array}{l}\text { SSRI induces weight loss } \\
\text { by increasing CRH level at } \\
\text { the paraventricular nucleus } \\
\text { of hypothalamus }\end{array}$ & Weight loss & Chow diet & Wieczorek et al. ${ }^{131}$ \\
\hline $\begin{array}{l}\text { Wild-type } \\
\text { Ay mice }\end{array}$ & $\begin{array}{l}\text { Treatment of } 30-60 \mathrm{mg} \mathrm{kg}^{-1} \text { of } \\
\text { milnacipran followed by food } \\
\text { presentation after } 30 \text { min. } \\
\text { Food intake measured after } 1 / 6 \mathrm{~h} \text {. } \\
\text { Study duration: } 3 \text { days }\end{array}$ & $\begin{array}{l}\text { Increased hypothalamic } \\
\text { POMC and CART }\end{array}$ & $\begin{array}{l}\text { Decreased food intake } \\
\text { and weight }\end{array}$ & Chow diet & Nanogaki et al..$^{132}$ \\
\hline Mice & Fluoxetine treatment $/ 48 \mathrm{~h}$ of fasting & & $\begin{array}{l}\text { Decrease in body weight } \\
\text { and food intake with } \\
\text { fluoxetine treatment }\end{array}$ & Chow diet & Sullivan et al..$^{133}$ \\
\hline Rats & $\begin{array}{l}\text { Early-life neonatal handling stress } \\
\text { followed by } 0.25 \mathrm{mg} \mathrm{kg}^{-1} \text { per day } \\
\text { of imipramine treatment from } \\
\text { days } 60 \text { to } 120\end{array}$ & & $\begin{array}{l}\text { Chronic imipramine } \\
\text { treatment decreased } \\
\text { craving for sweet pellets }\end{array}$ & Chow diet & Portella et al..$^{134}$ \\
\hline $\begin{array}{l}\text { Female } \\
\text { rats }\end{array}$ & $\begin{array}{l}30 \text { days of chronic stress (food } \\
\text { deprivation, restraint, forced } \\
\text { swimming test and flashing } \\
\text { light stress) followed by } 60 \text { days } \\
\text { of fluoxetine treatment }\end{array}$ & & $\begin{array}{l}\text { Decreased consumption of } \\
\text { sweet pellets with } \\
\text { fluoxetine treatment }\end{array}$ & Chow diet & Gamaro et al. ${ }^{135}$ \\
\hline Rats & $\begin{array}{l}\text { 7-day treatment of fluoxetine or } \\
\text { imipramine } 10 \mathrm{mg} \mathrm{kg}^{-1} \text { with } \\
\text { repeated restraint stress, followed } \\
\text { by } 177 \text { days of high-fat diet } \\
\text { during post-stress period }\end{array}$ & & $\begin{array}{l}\text { Increased body weight } \\
\text { and absolute caloric intake } \\
\text { during post-stress period }\end{array}$ & & $\begin{array}{l}\text { Mastronardi } \\
\text { et } \text { al. }^{130}\end{array}$ \\
\hline
\end{tabular}

(3-PUFA), and plant oils rich in 6-PUFA and 9-PUFA. ${ }^{119,120}$ Long-term DIO was accompanied with visceral obesity, glucose intolerance, hyperdyslipidaemia, hyperleptinaemia and hyperinsulinaemia. ${ }^{121}$

Optimal conditions for the DIO model involve genetically outbred environments as they provide genetic diversity, where some animals are prone to obesity while others are resistant to it. ${ }^{119}$ A well-established method for studying DIO in rodents involves classifying groups of animals as 'obesity-prone' and 'obesity-resistant' based on their body weight, body weight gain and/or body fat. ${ }^{119}$ Obesity-prone rats classified as early as after 5 days of high-fat-diet feeding already had distinguishable characteristics of metabolic dysregulation. Lipoprotein lipase activity, plasma leptin, triglycerides and glucose levels were all elevated. ${ }^{125}$ At week 5, obesity-prone rats had significantly higher epididymal and retroperitoneal fat pad weights in comparison with the obesity-resistant group. ${ }^{122}$ Metabolic changes included lipoprotein lipase activities, where the activities were higher in epididymal fat pads and lower in gastrocnemius muscles in the obesity-prone group. ${ }^{122}$ In C57BL/6 mice, mRNA levels of leptin receptor and NPY were elevated, whereas pro-opiomelanocortin mRNA expression was reduced in the obesity-prone group. ${ }^{126}$ Furthermore, plasma leptin and insulin levels were elevated, and there was increased activity of lipoprotein lipase in adipose tissue. ${ }^{124}$ In addition, there were increased glucose, non-esterified fatty acids, triglyceride levels in the plasma and elevated $\beta$ hydroxyacyl-CoAdehydrogenase activity in the muscle. ${ }^{124}$

\section{ANIMAL MODELS OF STRESS AND DIO}

In animal studies, the linkage between stress and obesity remains non-consolidated, and the degree of stress paradigm, persistency or frequency of repeated stressors has a role in modulating body weight. Manting et al. demonstrated that, when a high-fat diet was given to rats, there was dysregulation in lipid metabolism. ${ }^{127}$ Moreover, when the high-fat diet was given in the presence of chronic stress, there was exacerbation in lipid dysregulation, where higher levels of triglycerides and total cholesterol, and lower levels of HDL-cholesterol were observed. ${ }^{127}$ In another study, the combination of social stress and a prolonged high-fat diet led to consequent dysregulation in lipid metabolism, enhanced plasma levels of non-HDLs and accumulation of triglycerides in the intrahepatic tissue. ${ }^{128}$ On the other hand, when a high-fat diet was given to the flinder-sensitive line rat genetic model of depression, depressive-like behaviour was exacerbated. ${ }^{129}$ These animal studies highlight the fact that on top of the of high-fat diet effect, stress can exacerbate metabolic dysregulation.

\section{ANIMAL MODELS OF ANTIDEPRESSANT AND PARADOXICAL WEIGHT LOSS}

Currently, the existing animal models suggest that TCA and SSRI antidepressant administrations have been associated with 'paradoxical' weight loss and reduction in food consumption (Table 3). However, the relationship between antidepressant use, MDD and weight gain is complex; until recently, there had not been an animal paradigm that reproduced antidepressant-induced weight gain as observed in the clinical setting. In recent years, a novel animal paradigm that explains the weight trajectory of rodents during antidepressant treatment was developed by Mastronardi et al. ${ }^{130}$ This animal model involves stress-induced weight loss and consumption of a high-fat diet, aiming at following the long-term 
impact of antidepressant treatment in rodents. The novel animal paradigm suggests that short-term antidepressant treatment and stress, followed by a high-fat diet and long-term follow-up, has an important role in consolidating the role of antidepressant use in weight gain.

\section{CONCLUSION AND FUTURE DIRECTIONS}

In this review, we have discussed the relationship between MDD and obesity. Clinical findings have suggested that obesity could increase the risk of developing MDD, and vice versa. Several pathways may have a role in this interaction, including neuroendocrine, neuroimmune and neurotropic mechanisms. Among those, activation of the HPA axis occurs both during MDD/stress and obesity, making it the most accepted shared common pathophysiological pathways in both disorders. Leptin and insulin resistance are pathophysiological mechanisms that need to be further elucidated, along with the roles of the immune system and neurotropic factors.

Despite the concomitant occurrence of the frequent use of antidepressants and the high incidence of obesity in Western societies, additional studies are required to fully test our hypothesis that the rise in obesity rates is related at least in part to increasing antidepressant use, and to elucidate the mechanisms underlying antidepressant-induced weight gain. Numerous studies have investigated the effects of different classes of antidepressants on body weight. Previous clinical studies suggest that TCAs amitriptyline, nortriptyline and imipramine were associated with weight gain. Mirtazapine (SNRI) has been associated with increased weight gain. Studies have suggested that weight gain associated with antidepressants reflect the action of monoamine pathways, which include serotoninergic, adrenergic, histaminergic, cholinergic and dopaminergic receptors. It has been suggested that the mechanism behind weight gain induced by TCAs and mirtazapine (SNRI) involves affinity for histaminergic receptors. Histaminergic receptors have been shown to interact with orexigenic neuropeptides such as orexin A, NPY and ghrelin. Bupropion (SNRI) has been shown to induce significant weight loss via selective inhibition of dopamine. On the other hand, because of dispersion in clinical studies, the effect of SSRI on body weight remains still unclear. Despite the fact that SSRI use has been associated with weight loss during acute treatment, a number of studies have shown that SSRIs may be associated with long-term risk of weight gain. Long-term studies with very much extended periods are needed in order to understand long-term effects of SSRI on body weight.

In animal studies, the presence of stress in addition to high-fat diet has been shown to exacerbate metabolic dysregulation. However, further efforts to develop animal models to characterise and consolidate the linkage between stress and obesity are needed. Important factors that need to be considered in developing animal model of stress and obesity are the degree of stress paradigm, persistency or frequency of repeated stressors, type of diet used and duration of the study. At present, antidepressants have shown to induce 'paradoxical weight loss' and reduction in food consumption in most animal models; however, a newer paradigm shows that the combination of stress and antidepressants followed by long-term high-fat diet results in markedly increased weight, in excess of what is caused by high-fat diet alone.

In this review we highlight the fact that the relationship between antidepressant use, MDD and weight gain is complex. We emphasise the fact that it is important to develop animal paradigms that better mimic the clinical settings, and include lifestyle factors such as dietary choices. Furthermore, future studies are needed to elucidate the mechanisms underlying depression, obesity and antidepressant-induced weight gain, and to test the hypothesis proposed in this paper that the increasing exposure to antidepressants, defined as current or past use of antidepressant drugs, in the context of obesogenic diets and environments, is a contributory factor to the obesity epidemic.

\section{CONFLICT OF INTEREST}

The authors declare no conflict of interest.

\section{ACKNOWLEDGMENTS}

This study was supported by the grant APP1070935 from the National Health and Medical Research Council, Australia.

\section{REFERENCES}

1 Kupfer DJ, Frank E, Phillips ML. Major depressive disorder: new clinical, neurobiological, and treatment perspectives. Lancet 2012; 379: 1045-1055.

2 Association AM (2013). Policy H-440.842. Recognition of Obesity as a Disease.

3 World Health Organization (2012). In: Depression. Fact sheet No. 369.

4 Beevers CK. Introduction: Evidence-Based Practice for Major Depressive Disorder. In: Springer DW, Rubin A, Beevers CG (eds.), Treatment of depression in adolescents and adults.1st edn. John Wiley \& Sons, Inc.: Hoboken, NJ, 2011.

5 Greenberg PE, Fournier AA, Sisitsky T, Pike CT, Kessler RC The economic burden of adultswith major depressive disorder in the United States (2005 and 2010). J Clin Psychiatry 2015; 76: 155-162.

6 National Survey of Mental Health and Wellbeing: Summary of Results Statistics. Australian Bureau of Statistics: Canberra, Australia, 2007.

7 Data and statistics, prevalence of mental disorders. In: Noncommunicable Disease, Mental Health. World Health Organization: WHO regional office for Europe, 2014.

8 Finkelstein EA, Trogdon JG, Cohen JW, Dietz W. Annual medical spending attributable to obesity: payer- and service-specific estimates.Health Aff (Millwood) 2009; 28: w822-w831.

9 Flegal KM, Carroll MD, Kit BK, Ogden CL. Prevalence of obesity and trends in the distribution of body mass index among US adults, 1999-2010. JAMA 2012; 307: 491-497.

10 Park J, Morley TS, Kim M, Clegg DJ, Scherer PE. Obesity and cancer--mechanisms underlying tumour progression and recurrence. Nat Rev Endocrinol 2014; 10: 455-465.

11 Drager LF, Togeiro SM, Polotsky VY, Lorenzi-Filho G. Obstructive sleep apnea: a cardiometabolic risk in obesity and the metabolic syndrome. J Am Coll Cardiol 2013; 62: 569-576.

12 Jagielski AC, Brown A, Hosseini-Araghi M, Thomas GN, Taheri S. The association between adiposity, mental well-being, and quality of life in extreme obesity. PLOS ONE 2014; 9: e92859.

13 Rosmond R, Lapidus L, Mårin P, Björntorp P. Mental distress, obesity and body fat distribution in middle-aged men. Obes Res 1996; 4: 245-252.

14 Markowitz S, Friedman MA, Arent SM. Understanding the relation between obesity and depression: causal mechanisms and implications for treatment. Clin Psychol 2008; 15: 1-20.

15 Becker E, Margraf J, Türke V, Soeder U, Neumer S. Obesity and mental illness in a representative sample of young women. Int J Obes Relat Metab Disord 2001; 25: S5.

16 Onyike CU, Crum RM, Lee HB, Lyketsos CG, Eaton WW. Is obesity associated with major depression? Results from the Third National Health and Nutrition Examination Survey. Am J Epidemiol 2003; 158: 1139-1147.

17 Roberts RE, Deleger S, Strawbridge WJ, Kaplan GA. Prospective association between obesity and depression: evidence from the Alameda County Study. Int J Obes 2003; 27: 514-521.

18 Richardson LP, Davis R, Poulton R, McCauley E, Moffitt TE, Caspi A et al. A longitudinal evaluation of adolescent depression and adult obesity. Archiv Pediatr Adolesc Med 2003; 157: 739-745.

19 Akbaraly TN, Kivimäki M, Brunner EJ, Chandola T, Marmot MG, Singh-Manoux A et al. Association between metabolic syndrome and depressive symptoms in middle-aged adults: results from the Whitehall II study. Diabetes Care 2009; 32 . 499-504.

20 Kinder LS, Carnethon MR, Palaniappan LP, King AC, Fortmann SP. Depression and the metabolic syndrome in young adults: findings from the Third National Health and Nutrition Examination Survey. Psychosom Med 2004; 66: 316-322.

21 Gil K, Radziłłowicz P, Zdrojewski T, Pakalska-Korcala A, Chwojnicki K, Piwoński J et al. Relationship between the prevalence of depressive symptoms and metabolic syndrome. Results of the SOPKARD project. Kardiol Pol 2006; 64: 464. 
22 Heiskanen TH, Niskanen LK, Hintikka JJ, Koivumaa-Honkanen HT, Honkalampi KM, Haatainen KM et al. Metabolic syndrome and depression: a cross-sectional analysis. J Clin Psychiatry 2006; 67: 1422.

23 Räikkönen K, Matthews KA, Kuller LH. Depressive symptoms and stressful life events predict metabolic syndrome among middle-aged women: a comparison of World Health Organization, adult treatment panel III, and international diabetes foundation definitions. Diabetes Care 2007; 30: 872-877.

24 Rikknen K, Matthews KA, Kuller LH. The relationship between psychological risk attributes and the metabolic syndrome in healthy women: antecedent or consequence?. Metabolism 2002; 51: 1573-1577.

25 Larura AP, Debra JB, Gu Q. 2011. Antidepressant Use in Persons Aged 12 and Over: United States, 2005-2008, NCHS Data Brief No. 76.

26 OECD Health at a Glance: Europe 2012. OECD Publishing: Paris, France, 2012.

27 Australian Health Survey: First Results, 2011-12. Mental Health Series Australian Institute of Health and Welfare: Canberra, Australia, 2012.

28 Diagnostic and Statistical Manual Mental Disorders-V. American Psychiatric Association: Washington, DC, 2013; vol. V.

29 Duman RS, Monteggia LM. A neurotrophic model for stress-related mood disorders. Biol Psychiatry 2006; 59: 1116-1127.

30 Wong M-L, Licinio J. From monoamines to genomic targets: a paradigm shift for drug discovery in depression. Nat Rev Drug Discov 2004; 3: 136-151.

31 Pariante CM, Lightman SL. The HPA axis in major depression: classical theories and new developments. Trends Neurosci 2008; 31: 464-468.

32 Vreeburg SA, Hoogendijk WG, van Pelt J, Derijk RH, Verhagen JC, van Dyck R et al. Major depressive disorder and hypothalamic-pituitary-adrenal axis activity: Results from a large cohort study. Arch Gen Psychiatry 2009; 66: 617-626.

33 Trejo JL, Llorens-Martín MV, Torres-Alemán I. The effects of exercise on spatial learning and anxiety-like behavior are mediated by an IGF-I-dependent mechanism related to hippocampal neurogenesis. Mol Cell Neurosci 2008; 37: 402-411.

34 Hoshaw BA, Malberg JE, Lucki I. Central administration of IGF-I and BDNF leads to long-lasting antidepressant-like effects. Brain Res 2005; 1037: 204-208.

35 Malberg JE, Platt B, Rizzo SJS, Ring RH, Lucki I, Schechter LE et al. Increasing the levels of insulin-like growth factor-I by an IGF binding protein inhibitor produces anxiolytic and antidepressant-like effects. Neuropsychopharmacology 2007; 32: 2360-2368.

36 Duman $\mathrm{CH}$, Schlesinger L, Terwilliger R, Russell DS, Newton SS, Duman RS. Peripheral insulin-like growth factor-I produces antidepressant-like behavior and contributes to the effect of exercise. Behav Brain Res 2009; 198: 366-371.

37 Jow G-M, Yang T-T, Chen C-L. Leptin and cholesterol levels are low in major depressive disorder, but high in schizophrenia. J Affect Disord 2006; 90: 21-27.

38 Kraus T, Haack M, Schuld A, Hinze-Selch D, Pollmaecher T. Low leptin levels but normal body mass indices in patients with depression or schizophrenia. Neuroendocrinology 2001; 73: 243-247.

39 Westling S, Ahrén B, Träskman-Bendz L, Westrin Å. Low CSF leptin in female suicide attempters with major depression. J Affect Disord 2004; 81: 41-48.

40 Atmaca M, Kuloglu M, Tezcan E, Ustundag B, Gecici O, Firidin B. Serum leptin and cholesterol values in suicide attempters. Neuropsychobiology 2002; 45: 124-127.

41 Schilling C, Gilles M, Blum WF, Daseking E, Colla M, Weber-Hamann B et al. Leptin plasma concentrations increase during antidepressant treatment with amitriptyline and mirtazapine, but not paroxetine and venlafaxine: leptin resistance mediated by antihistaminergic activity? J Clin Psychopharmacol 2013; 33: 99-103.

42 Lu X-Y, Kim CS, Frazer A, Zhang W. Leptin: a potential novel antidepressant. Proc Natl Acad Sci USA 2006; 103: 1593-1598.

43 Loftis JM, Huckans M, Morasco BJ. Neuroimmune mechanisms of cytokineinduced depression: current theories and novel treatment strategies. Neurobiol Dis 2010; 37: 519-533.

44 Van Leeuwen JT. Antidepressants : Types, Efficiency and Possible Side Effects. Nova Science Publishers: New York, NY, USA, 2010.

45 Castren E. Is mood chemistry? Nat Rev Neurosci 2005; 6: 241-246.

46 Duman RS, Heninger GR, Nestler EJ. A molecular and cellular theory of depression. Arch Gen Psychiatry 1997; 54: 597-606.

47 Zhao C, Deng W, Gage FH. Mechanisms and functional implications of adult neurogenesis. Cell 2008; 132: 645-660.

48 Romero-Corral A, Somers VK, Sierra-Johnson J, Thomas RJ, Collazo-Clavell ML, Korinek $\mathrm{J}$ et al. Accuracy of body mass index in diagnosing obesity in the adult general population. Int J Obes (Lond) 2008; 32: 959-966.

49 Wolin KY, Petrelli JM. Obesity. Greenwood Press: Santa Barbara, CA, USA, 2009.

50 O'Neill S, O'Driscoll L. Metabolic syndrome: a closer look at the growing epidemic and its associated pathologies. Obes Rev 2015; 16: 1-12.

51 Alberti KG, Eckel RH, Grundy SM, Zimmet PZ, Cleeman Jl, Donato KA et al. Harmonizing the metabolic syndrome: a joint interim statement of the International Diabetes Federation Task Force on Epidemiology and Prevention; National Heart, Lung, and Blood Institute; American Heart Association; World
Heart Federation; International Atherosclerosis Society; and International Association for the Study of Obesity. Circulation 2009; 120: 1640-1645.

52 Bornstein SR, Schuppenies A, Wong ML, Licinio J. Approaching the shared biology of obesity and depression: the stress axis as the locus of geneenvironment interactions. Mol Psychiatry 2006; 11: 892-902.

53 Scott KM, Bruffaerts R, Simon GE, Alonso J, Angermeyer M, de Girolamo G et al. Obesity and mental disorders in the general population: results from the world mental health surveys. Int J Obes (Lond) 2008; 32: 192-200.

54 de Wit L, Luppino F, van Straten A, Penninx B, Zitman F, Cuijpers P. Depression and obesity: a meta-analysis of community-based studies. Psychiatry Res 2010; 178: $230-235$.

55 Luppino FS, de Wit LM, Bouvy PF, Stijnen T, Cuijpers P, Penninx BW et al. Overweight, obesity, and depression: a systematic review and meta-analysis of longitudinal studies. Arch Gen Psychiatry 2010; 67: 220-229.

56 Luppino FSDWLM, Bouvy PF, Stijnen T, Cuijpers P, Penninx BJJ, Zitman FG. Overweight, obesity, and depression: a systemic review and meta-analysis of longitudinal studies. Arch Gen Psychiatry 2010; 67: 220-229.

57 Hasler G, Pine DS, Kleinbaum DG, Gamma A, Luckenbaugh D, Ajdacic V et al. Depressive symptoms during childhood and adult obesity: the Zurich Cohort Study. Mol Psychiatry 2005; 10: 842-850.

58 Vogelzangs N, Kritchevsky SB, Beekman AT, Newman AB, Satterfield S, Simonsick $\mathrm{EM}$ et al. Depressive symptoms and change in abdominal obesity in older persons. Arch Gen Psychiatry 2008; 65: 1386-1393.

59 Qi L, Cho YA. Gene-environment interaction and obesity. Nutr Rev 2008; 66: 684-694.

60 Lin RC, Wang XL, Dalziel B, Caterson ID, Morris BJ. Association of obesity, but not diabetes or hypertension, with glucocorticoid receptor N363S variant. Obes Res 2003; 11: 802-808.

61 Challis BG, Luan J, Keogh J, Wareham NJ, Farooqi IS, O'Rahilly S. Genetic variation in the corticotrophin-releasing factor receptors: identification of singlenucleotide polymorphisms and association studies with obesity in UK Caucasians. Int J Obes Relat Metab Disord 2004; 28: 442-446.

62 Lang UE, Hellweg R, Sander T, Gallinat J. The Met allele of the BDNF Val66Met polymorphism is associated with increased BDNF serum concentrations. Mol Psychiatry 2009; 14: 120-122.

63 Pan A, Keum N, Okereke Ol, Sun Q, Kivimaki M, Rubin RR et al. Bidirectional association between depression and metabolic syndrome: a systematic review and meta-analysis of epidemiological studies. Diabetes Care 2012; 35: 1171-1180.

64 Vancampfort D, Correll CU, Wampers M, Sienaert P, Mitchell AJ, De Herdt A et al. Metabolic syndrome and metabolic abnormalities in patients with major depressive disorder: a meta-analysis of prevalences and moderating variables. Psychol Med 2014; 44: 2017-2028.

65 Björntorp P. Do stress reactions cause abdominal obesity and comorbidities? Obes Rev 2001; 2: 73-86.

66 Schüle C. Neuroendocrinological mechanisms of actions of antidepressant drugs. J Neuroendocrinol 2007; 19: 213-226.

67 Shelton RC, Falola M, Li L, Zajecka J, Fava M, Papakostas Gl. The pro-inflammatory profile of depressed patients is (partly) related to obesity. J Psychiatr Res 2015; 70: 91-97.

68 Wimbiscus M, Kostenko O, Malone D. MAO inhibitors: risks, benefits, and lore. Cleve Clin J Med 2010; 77: 859-882.

69 Fiedorowicz JG, Swartz KL. The role of monoamine oxidase inhibitors in current psychiatric practice. J Psychiatr Pract 2004; 10: 239.

70 Crane GE. Iproniazid (marsilid) phosphate: a therapeutic agent for mental disorders and debilitating diseases. Psychiatr Res Rep 1957; 8: 142-152.

71 Yıldız A, Gönül AS, Tamam L. Mechanism of actions of antidepressants: beyond the receptors. Bull Clin Psychopharmacol 2002; 12: 194-200.

72 Fangmann P, Assion H-J, Juckel G, González CÁ, López-Muñoz F. Half a century of antidepressant drugs: on the clinical introduction of monoamine oxidase inhibitors, tricyclics, and tetracyclics. Part II: tricyclics and tetracyclics. J Clin Psychopharmacol 2008; 28: 1-4.

73 Roose SP, Laghrissi-Thode F, Kennedy JS, Nelson JC, Bigger JT Jr, Pollock BG et al. Comparison of paroxetine and nortriptyline in depressed patients with ischemic heart disease. JAMA 1998; 279: 287-291.

74 Kantor SJ, Glassman AH, Bigger JT, Perel JM, Giardina EV. The cardiac effects of therapeutic plasma concentrations of imipramine. Am J Psychiatry 1978; 135: 534-538.

75 Glassman AH, Roose SP, Bigger J Jr.. The safety of tricyclic antidepressants in cardiac patients: Risk-benefit reconsidered. JAMA 1993; 269: 2673-2675.

76 Berken GH, Weinstein DO, Stern WC. Weight gain: a side-effect of tricyclic antidepressants. J Affect Disord 1984; 7: 133-138.

77 Wong DT, Bymaster FP, Engleman EA. Prozac (Fluoxetine, Lilly 110140), the first selective serotonin uptake inhibitor and an antidepressant drug: twenty years since its first publication. Life Sci 1995; 57: 411-441. 
78 Vaswani M, Linda FK, Ramesh S. Role of selective serotonin reuptake inhibitors in psychiatric disorders: a comprehensive review. Prog NeuroPsychopharmacol Biol Psychiatry 2003; 27: 85-102.

79 Cascade E KA, Kennedy. SH. Real-world data on SSRI antidepressant side effects. Psychiatry (Edgmont) 2009; 6: 16-18.

80 Sussman N, Ginsberg D. Rethinking side effects of the selective serotonin reuptake inhibitors: sexual dysfunction and weight gain. Psychiatr Ann 1998; 28: 89-97.

81 Ferguson JM. SSRI antidepressant medications: adverse effects and tolerability. Prim Care Companion J Clin Psychiatry 2001; 3: 22.

82 Goldstein BJ, Goodnick PJ. Selective serotonin reuptake inhibitors in the treatment of affective disorders-III. Tolerability, safety and pharmacoeconomics. J Psychopharmacol 1998; 12(4 suppl): 55-S87.

83 Mackay FJ, Dunn NR, Wilton LV, Pearce GL, Freemantle SN, Mann RD. A comparison of fluvoxamine, fluoxetine, sertraline and paroxetine examined by observational cohort studies. Pharmacoepidemiol Drug Safety 1997; 6: 235-246.

84 Nelson JC, Mazure CM, Bowers MB Jr, Jatlow PI. A preliminary, open study of the combination of fluoxetine and desipramine for rapid treatment of major depression. Arch Gen Psychiatry 1991; 48: 303.

85 Seth R, Jennings A, Bindman J, Phillips J, Bergmann K. Combination treatment with noradrenalin and serotonin reuptake inhibitors in resistant depression. $\mathrm{Br} J$ Psychiatry 1992; 161: 562-565.

86 Briley M. Specific serotonin and noradrenaline reuptake inhibitors (SNRIs). A review of their pharmacology, clinical efficacy and tolerability. Hum Psychopharmacol 1998; 13: 99-111.

87 Van Reedt Dortland AKB, Giltay EJ, Van Veen T, Zitman FG, Penninx BWJH. Metabolic syndrome abnormalities are associated with severity of anxiety and depression and with tricyclic antidepressant use. Acta Psychiatr Scand 2010; 122: 30-39.

88 Kivimäki M, Hamer M, Batty GD, Geddes JR, Tabak AG, Pentti J et al. Antidepressant medication use, weight gain, and risk of type 2 diabetes a population-based study. Diabetes Care 2010; 33: 2611-2616.

89 Patten S, Williams J, Lavorato D, Brown L, McLaren L, Eliasziw M. Major depression, antidepressant medication and the risk of obesity. Psychother Psychosom 2009; 78: 182.

90 Andersen S, Clemow D, Corya S. Long-term weight gain in patients treated with open-label olanzapine in combination with fluoxetine for major depressive disorder. J Clin Psychiatry 2005; 66: 1468.

91 Dannon P II, Lowengrub K, Gonopolsky Y, Musin E, Grunhaus L, Kotler M. A naturalistic long-term comparison study of selective serotonin reuptake inhibitors in the treatment of panic disorder. Clin Neuropharmacol 2007; 30: 326-334.

92 Michelson D, Amsterdam JD, Quitkin FM, Reimherr FW, Rosenbaum JF, Zajecka J et al. Changes in weight during a 1-year trial of fluoxetine. Am J Psychiatry 1999; 156: $1170-1176$

93 Sussman N, Ginsberg DL, Bikoff J. Effects of nefazodone on body weight: a pooled analysis of selective serotonin reuptake inhibitor-and imipraminecontrolled trials. J Clin Psychiatry 2001; 62: 256.

94 Uher R, Mors O, Hauser J, Rietschel M, Maier W, Kozel D et al. Changes in body weight during pharmacological treatment of depression. Int J NeuroPsychopharmacol 2011; 14: 367.

95 Serretti A ML. Antidepressants and body weight: a comprehensive review and meta-analysis. J Clin Psychiatry 2010; 71: 1259-1271.

96 Apovian CM, Aronne LJ, Bessesen DH, McDonnell ME, Murad MH, Pagotto $U$ et al. Pharmacological management of obesity: an endocrine Society clinical practice guideline. J Clin Endocrinol Metab 2015; 100: 342-362.

97 Christos T, George P, Charalabos P, Dimitris D, Vasilis M, Constantin K et al. Excessive weight gain after remission of depression in a schizophrenic patient treated with risperidone: case report. BMC Psychiatry 2006; 6: 37

98 Bouwer C, Harvey B. Phasic craving for carbohydrate observed with citalopram. Int Clin Psychopharmacol 1996; 11: 273.

99 Harvey B BC. Neuropharmacology of paradoxic weight gain with selective serotonin reuptake inhibitors. Clin Neuropharmacol 2000; 23: 90-97.

100 Pinar M, Gulsun M, Tasci I, Erdil A, Bolu E, Acikel C et al. Maprotiline induced weight gain in depressive disorder: Changes in circulating ghrelin and adiponectin levels and insulin sensitivity. Prog Neuro-Psychopharmacol Biol Psychiatry 2008; 32: 135-139.

101 Ishizuka T, Nomura S, Hosoda H, Kangawa K, Watanabe T, Yamatodani A. A role of the histaminergic system for the control of feeding by orexigenic peptides. Physiol Behav 2006; 89: 295-300.

102 Billes SK, Sinnayah P, Cowley MA. Naltrexone/bupropion for obesity: an investigational combination pharmacotherapy for weight loss. Pharmacol Res 2014; 84. 1-11.

103 Moosa MYH, Panz VR, Jeenah FY, Joffe BI. African women with depression: the effect of imipramine and fluoxetine on body mass index and leptin secretion. J Clin Psychopharmacol 2003; 23: 549-552.
104 Dryden S, Frankish H, Wang Q, Pickavance L, Williams G. The serotonergic agent fluoxetine reduces neuropeptide $Y$ levels and neuropeptide $Y$ secretion in the hypothalamus of lean and obese rats. Neuroscience 1996; 72: 557-566.

105 Bhatia N, Maiti PP, Choudhary A, Tuli A, Masih D, Khan MMU et al. Animal models and stress. Int J Pharm Sci Res 2010; 2: 1147-1155.

106 Willner P. The validity of animal models of depression. Psychopharmacology 1984; 83: 1-16.

107 Belzung C, Lemoine M. Criteria of validity for animal models of psychiatric disorders: focus on anxiety disorders and depression. Biol Mood Anxiety Disord 2011; 1: 9.

108 Steru L, Chermat R, Thierry B, Simon P. The tail suspension test: a new method for screening antidepressants in mice. Psychopharmacology 1985; 85: 367-370.

109 Nestler EJ, Gould E, Manji H. Preclinical models: status of basic research in depression. Biol Psychiatry 2002; 52: 503-528.

110 Tye KM, Prakash R, Kim S-Y, Fenno LE, Grosenick L, Zarabi H et al. Amygdala circuitry mediating reversible and bidirectional control of anxiety. Nature 2011; 471: 358-362.

111 Yan H-C, Cao X, Das M, Zhu X-H, Gao T-M. Behavioral animal models of depression. Neurosci Bull 2010; 26: 327-337.

112 Vorhees CV, Williams MT. Morris water maze: procedures for assessing spatial and related forms of learning and memory. Nat Protoc 2006; 1: 848-858.

113 Willner P, Towell A, Sampson D, Sophokleous S, Muscat R. Reduction of sucrose preference by chronic unpredictable mild stress, and its restoration by a tricyclic antidepressant. Psychopharmacology 1987; 93: 358-364.

114 Tschöp M, Heiman ML. Rodent obesity models: an overview. Exp Clin Endocrinol Diabetes 2001; 109: 307-319.

115 Chehab FF, Qiu J, Ogus S. The use of animal models to dissect the biology of leptin. Recent Prog Hormone Res 2004; 59: 245-266.

116 Zhang Y, Proenca R, Maffei M, Barone M, Leopold L, Friedman JM. Positional cloning of the mouse obese gene and its human homologue. Nature 1994; 372 425-432.

117 Frederich RC, Hamann A, Anderson S, Löllmann B, Lowell BB, Flier JS. Leptin levels reflect body lipid content in mice: evidence for diet-induced resistance to leptin action. Nat Med 1995; 1: 1311-1314.

118 Stephens TW, Basinski M, Bristow PK, Bue-Valleskey JM, Burgett SG, Craft L et al. The role of neuropeptide $\mathrm{Y}$ in the antiobesity action of the obese gene product. Nature 1995; 377: 530-532.

119 Hariri N, Thibault L. High-fat diet-induced obesity in animal models. Nutr Res Rev 2010; 23: 270.

120 Buettner R, Schölmerich J, Bollheimer LC. High-fat diets: Modeling the metabolic disorders of human obesity in rodents. Obesity 2007; 15: 798-808.

121 Madsen AN, Hansen G, Paulsen SJ, Lykkegaard K, Tang-Christensen M, Hansen $\mathrm{HS}$ et al. Long-term characterization of the diet-induced obese and diet-resistant rat model: a polygenetic rat model mimicking the human obesity syndrome. $J$ Endocrinol 2010; 206: 287-296.

122 Pagliassotti MJ, Knobel SM, Shahrokhi KA, Manzo AM, Hill JO. Time course of adaptation to a high-fat diet in obesity-resistant and obesity-prone rats. Am J Physiol 1994; 267: R659-R664.

123 Huang BW, Chiang MT, Yao HT, Chiang W. The effect of high-fat and highfructose diets on glucose tolerance and plasma lipid and leptin levels in rats. Diabetes Obes Metab 2004; 6: 120-126.

124 Dourmashkin JT, Chang GQ, Gayles EC, Hill JO, Fried SK, Julien C et al. Different forms of obesity as a function of diet composition. Int J Obes Relat Metab Disord 2005; 29: 1368-1378.

125 Dourmashkin JT, Chang GO, Hill JO, Gayles EC, Fried SK, Leibowitz SF. Model for predicting and phenotyping at normal weight the long-term propensity for obesity in Sprague-Dawley rats. Physiol Behav 2006; 87: 666-678.

126 Huang XF, Xin X, McLennan P, Storlien L. Role of fat amount and type in ameliorating diet-induced obesity: insights at the level of hypothalamic arcuate nucleus leptin receptor, neuropeptide $\mathrm{Y}$ and pro-opiomelanocortin mRNA expression. Diabetes Obes Metab 2004; 6: 35-44.

127 Manting $L$, Haihong $Z$, Jing $L$, Shaodong $C$, Yihua $L$. The model of rat lipid metabolism disorder induced by chronic stress accompanying high-fat-diet Lipids Health Dis 2011; 28: 153.

128 Chuang J-C, Cui H, Mason BL, Mahgoub M, Bookout AL, Yu HG et al. Chronic social defeat stress disrupts regulation of lipid synthesis. J Lipid Res 2010; 51: 1344-1353.

129 Abildgaard A, Solskov L, Volke V, Harvey BH, Lund S, Wegener G. A high-fat diet exacerbates depressive-like behavior in the Flinders Sensitive Line (FSL) rat, a genetic model of depression. Psychoneuroendocrinology 2011; 36: 623-633.

130 Mastronardi C, Paz-Filho GJ, Valdez E, Maestre-Mesa J, Licinio J, Wong ML. Longterm body weight outcomes of antidepressant-environment interactions. $\mathrm{Mo}$ Psychiatry 2011; 16: 265-272.

131 Wieczorek I, Schulz C, Jarry H, Lehnert H. The effects of the selective serotonin reuptake-inhibitor fluvoxamine on body weight in Zucker rats are mediated by corticotropin-releasing hormone. Int J Obes 2001; 25: 1566-1569. 
132 Nonogaki K, Nozue K, Kuboki T, Oka Y. Milnacipran, a serotonin and norepinephrine reuptake inhibitor, induces appetite-suppressing effects without inducing hypothalamic stress responses in mice. Am J Physiol Regul Integr Comp Physiol 2007; 292: R1775-R1781.

133 Sullivan SD, Howard LC, Clayton AH, Moenter SM. Serotonergic activation rescues reproductive function in fasted mice: Does serotonin mediate the metabolic effects of leptin on reproduction? Biol Reprod 2002; 66: 1702-1706.

134 Portella AK, Silveira PP, Diehl LA, Crema LM, Clemente Z, Peres W et al. Early life handling decreases serotonin turnover in the nucleus accumbens and affects feeding behavior of adult rats. Dev Psychobiol 2010; 52: 190-196.
135 Gamaro GD, Prediger ME, Lopes J, Bassani MG, Dalmaz C. Fluoxetine alters feeding behavior and leptin levels in chronically-stressed rats. Pharmacol Biochem Behav 2008; 90: 312-317.

\section{cc) (i)}

This work is licensed under a Creative Commons Attribution 4.0 International License. The images or other third party material in this article are included in the article's Creative Commons license, unless indicated otherwise in the credit line; if the material is not included under the Creative Commons license, users will need to obtain permission from the license holder to reproduce the material. To view a copy of this license, visit http://creativecommons.org/licenses/ by/4.0/ 